\title{
Beyond Figuration and Narration: Deleuzian Approaches to Gwen John's Paintings
}

\author{
Maria Tamboukou University of East London
}

\begin{abstract}
In this paper I trace pictorial acts that move beyond figuration and narration, particularly focusing on Gwen John's portraits of women and girls, the work of her maturity as an artist. In doing this I make connections between John's and Cézanne's letters about their painting techniques and direction. The analysis draws on Deleuze and Guattari's approaches to the work of art. I discuss in particular the concept of faciality in the Thousand Plateaus and the problem of painting forces in Deleuze's work on Bacon, The Logic of Sensation. My argument is that an analysis that goes beyond phenomenology and semiotics opens new ways of seeing and appreciating a modernist woman artist's paintings, and sheds new light on the way her art allows the female figure to emerge as a woman-becoming-imperceptible within a patriarchal regime of signs.
\end{abstract}

Keywords: Gwen John, Cézanne, faciality, colourism, rhythm, form, painting forces, becoming-imperceptible I learnt so much at those two visits. I didn't know how much till now. Some
things I had found out but it was satisfactory to have them confirmed and
expressed well. For instance, I said 'a cat or a man, it's the same thing', you
looked rather surprised. I meant it's an affair of volumes.

NLW MS 21468D, ff. 180v

In August 1936 Gwen John ${ }^{1}$ an expatriate Welsh artist, who mostly lived and worked in Paris, was writing to her artist friend and fellow student 
at the Slade, Ursula Tyrwhitt, a letter containing a significant albeit strange statement: “"a cat or a man, it's the same thing" [...] it's an affair of volumes'. This epistolary extract concentrates in a rather radical and provocative way the artist's ideas around art in general and painting techniques in particular: although John's work was mainly revolving around portraits of women and young girls, her art moved beyond the conventions and constraints of figurative painting. In this paper I trace pictorial acts that move beyond figuration and narration, particularly focusing on John's portraits of women and girls, the work of her maturity as an artist. In doing this, I follow approaches to the work of art informed by Deleuze and Guattari's philosophies. My argument is that an analysis that goes beyond phenomenology and semiotics opens new ways of seeing and appreciating a modernist woman artist's paintings and can shed new light on the way her art allows the female figure to emerge as a woman-becoming-imperceptible within a patriarchal regime of signs.

\section{Portraits and Faces}

Gwen John was mostly a portrait painter although she also did some still lives, landscapes and in the early phases of her work she drew and painted her cat a $\operatorname{lot}^{2}$ Since the early phases of the appraisal of her work, John's portraits have been discussed 'as of feminine gentleness, delicacy and refinement ... a world of pale spinster passions ... modest paintings of lone women in domestic interiors' (Tickner 2004: 31-2). John's lonely figures have further invoked strong affects and enthusiastic critical responses; what is recurring in the range of critical appreciations of John's work is the centrality of the face in the discussions that revolve around her portraits. But the face is also central in Deleuze and Guattari's analyses; as Ronald Bogue has noted: 'the human face [is] a key component not only in painting but in the functioning of language and sign systems, the formation of subjectivity and the deployment of power relations' (Bogue 2003: 79).

Bogue discusses language in the context of what Deleuze and Guattari have theorised as 'regimes of signs' (Deleuze and Guattari 1988), wherein body and language are interrelated and thus 'the configuration of the face is inextricably tied to the evolution of the voice' (Bogue 2003: 81). Moreover, language is not seen within the structuralist frame of Saussurean linguistics 'as a self-referential system of acoustic images (signifiers) and mental concepts (signifieds)' (Bogue 2003: 82). For Deleuze and Guattari, language is considered as action and is 
charted within larger socio-historical and cultural networks, multilevelled assemblages of actions:

We call any specific formalization of expression a regime of signs, at least when the expression is linguistic. A regime of signs constitutes a semiotic system. But it appears difficult to analyse semiotic systems in themselves: there is always a form of content that is simultaneously inseparable from and independent of the form of expression and the two forms pertain to assemblages that are not principally linguistic. (Deleuze and Guattari 1988: 111)

What is the role of the face then within the polyvalent regimes of signs? According to Deleuze and Guattari, the face is central in a process, which they call faciality: 'the face crystallises all redundancies, it emits and receives, releases and recaptures signifying signs ... the face is the Icon proper to the signifying regime' (Deleuze and Guattari 1988: 115). Faciality is then a material process, '[reigning] over that whole constellation of significances and interpretations' (115). Faciality further depends on the specific regime of signs it is related to. In Deleuze and Guattari's (1988) analyses there are four semiotic systems or regimes of signs: (1) a presignifying primitive regime; (2) a signifying despotic regime; (3) a postsignifying passional regime; and (4) a countersignifying nomadic regime. ${ }^{3}$ These historically conditioned systems have their own principles and characteristics, although they always overlap and interact with each other. The role of the face is crucial within the despotic and the passional regime, but not important in the primitive regime, while the face in the nomadic regime is not really elaborated. In his commentary of the despotic regime, Bogue gives a comprehensive outline of its properties and constitutive elements:

The biunivocal correlation of signifier and signified, the dominance of the arbitrary signifier over the signified, the identification of the signifier with law and authority ... the positioning of signifiers in an infinite chain of self-referential interpretation - all are characteristics of the despotic regime [ultimately associated] with the state form of social organisation. (Bogue 2003: 83)

While 'the despot becomes the unifying source of all signification' (Bogue 2003: 84), there is no central organisation in the passional regime; signs are rather organised 'in relation to an obsessional point of subjectification, an object of fixation from which issue two forms of the subject: the subject of enunciation [the one who speaks] and the subject of the statement [the one who is spoken of]' (Bogue 2003: 84). In this light, the face that is most interesting for Deleuze and Guattari's analyses 
is the face that is effectuated by both the despotic and the passional regime, the face 'that brings together a despotic wall of interconnected signifiers and passional black holes of subjective absorption' (Bogue 2003: 90), what Deleuze and Guattari call the white wall-black hole system (Deleuze and Guattari 1988: 167).

Indeed, Deleuze and Guattari stress the way language and faces are inextricably linked, and point to the multifarious ways that faces visualise and sustain 'arborescences and dichotomies' (Deleuze and Guattari 1988: 179). What is therefore distinctive about Deleuze and Guattari's approach is the way they link facial expressions to the function of the disciplinary society, particularly stressing the role of the face in processes of subjectification. While charting the codification of the face, Deleuze and Guattari have also considered lines of flight: 'how do you get out of the black hole? How do you break through the wall? How do you dismantle the face?' (186). Dismantling the face, becoming imperceptible through colour, flying away towards the realm of the faceless, this is then 'the problem' of painting for Deleuze and Guattari. But, how can you deterritorialise the face when painting portraits? The painter can do that, Deleuze argues, by liberating lines and colours on her canvas (Deleuze 2003: 52). ${ }^{4}$ Cézanne, upon whom Deleuze draws, has emphasised the function of lines and colours in painting:

Lines parallel to the horizon give breadth . . lines perpendicular to the horizon give depth. But nature for us [men] is more depth than surface, whence the need to introduce into our light vibrations, represented by the reds and yellows, a sufficient amount of blueness to give the feel of air. ${ }^{5}$

Liberating lines or colours thus becomes crucial: 'it is through colour that you become imperceptible' (Deleuze 2003: 187). Deleuze's work on Bacon has taken this proposition further and it is to artistic actions of dismantling the face and becoming imperceptible through the modulation of colour that I have focused my analysis on John's portraits. Having discussed faces and the concept of faciality in Deleuze and Guattari's vocabulary, my second move will now be to clarify the distinction between the figurative and the figural in Deleuze's thought.

\section{On the Figure and the Motif}

Deleuze discusses the problem of the figure drawing on Jean-François Lyotard's concept of the figural, noting in a footnote how Lyotard uses it 'as a substantive in order to oppose it to the figurative' (Deleuze 2003: 173). Deleuze's footnote is the only reference to Lyotard in his book 
on Bacon, since there are differences between his and Lyotard's take on the notion of the figural: while Lyotard makes connections between the figural and the unconscious, Deleuze 'relates the figural to sensation, affect and the play of material forces' (Bogue 2003: 116). Although Bogue acknowledges and discusses these differences, he nevertheless argues that Lyotard's notion is important in understanding Deleuze's analysis.

In Lyotard's (1971) exposition of the concept then, 'language points to a world outside itself and thereby opens itself to the visual' (Bogue 2003: 113). But how can the 'truth' of the visual be disclosed? If it becomes readable and enters the order of language, then its truth is lost. It is only in the event ${ }^{6}$ that its truth can emerge; as an event, the figural disrupts temporal and spatial orders and creates conditions of possibility 'for the essential heterogeneity of the visual field [to be] approached' (Lyotard cited in Bogue 2003: 114).

Andrew Gibson has further noted that 'the figural' in Lyotard's thought is an energetic and transgressive force, which violates the rules of discourse, refuses to respect the laws of its invariants and its spacings, and cannot be accommodated within any account of pure forms (Gibson 1996: 61).

Genealogical approaches to the history of painting in general and of portraiture in particular have indeed unveiled significant events in the process of artistic creation and reception. ${ }^{7}$ More specifically, Cézanne's and Bacon's work have been considered in Deleuze's analysis as critical events in artistic practices of dismantling the face, going beyond the boundaries of illustrative and narrative art and introducing new ideas and techniques in the modulation of colour. In this genealogical line then, John's paintings and particularly her self-portraits and portraits of women will be seen as events in the visualisation of the female figure in its Deleuzian conceptualisation, as a bloc of sensations, affects and percepts, a theme that I will now follow.

In discussing the figural, Lyotard has suggested that 'to learn to see is to unlearn to recognise' (Lyotard 1971: 114). How can painting contribute to this process of unlearning? Since the figural is not connected to the unconscious for Deleuze, his suggestion is embedded within the material assemblage of painting practices:

The Painter has many things in [his] head, or around him, or in his studio. Now everything he has in his head or around him is already in the canvas, more or less virtually, more or less actually, before he begins his work. They are all present in the canvas as so many images, actual or virtual, so that 
the painter does not have to cover a blank surface, but rather would have to empty it out, clear it, clean it. (Deleuze 2003: 86)

For Deleuze, therefore, 'the painter's problem is not how to enter into the canvas, since [he] is already there, but how to get out of it, getting out of clichés, getting out of probability' (Deleuze 2003: 96). Escaping clichés, following lines of flight, create conditions of possibility for the work of art to emerge as 'a bloc of sensations ... a compound of percepts and affects .... a monument standing up alone' (Deleuze and Guattari 1994: 164). But once the painter has deterritorialised herself from the striated spaces of the canvas, she still needs to return to it, open up smooth spaces and confront the chaos of the world and the infinity of time through creation. 'Perhaps the peculiarity of art is to pass through the finite in order to rediscover, to restore the infinite', Deleuze and Guattari have poetically noted (Deleuze and Guattari 1994: 197). Here, Cézanne's ideas of grasping the moment through painting, opens up a plane of new possibilities: 'A minute of the world goes by. To paint it in its reality! And to forget everything else. To become reality itself' (in Doran 2001: 115). Indeed, Cézanne's idea of 'becoming the minute' is at the heart of Deleuze and Guattari's discussion of the work of art as a compound of sensations, percepts, affects and becomings:

It is Mrs Dalloway who perceives the town-but because she has passed into the town like 'a knife through everything' and becomes imperceptible herself. Affects are precisely the nonhuman becomings of man, just as perceptsincluding the town-are non human landscapes of nature. (Deleuze and Guattari 1994: 169; original emphasis)

But 'to become with the world' (Deleuze and Guattari 1994: 169), painters have to overcome the prejudices, biases and clichés they were nurtured with and face the world and their canvas with fresh eyes and clear minds. Only then, Cézanne argues, can the artist become 'a receptacle of sensations' (in Doran 2001: 111) and can render her mind 'a photographic plate' where the evanescent forces of nature can be recorded and transferred to, 'translated' into the canvas. What is interesting in Cézanne's urge above is the importance of 'forgetting' as a precondition for painting the reality of the fleeting moment.

'Memory plays a small part in art', Deleuze and Guattari have notably argued (Deleuze and Guattari 1994: 167). This anti-memory stance may seem to contradict their idea that the work of art should be conceived as a monument, standing up alone (164). But the monument in Deleuze and Guattari's discussion of art 'is not something commemorating a past, it is a bloc of present sensations that owe their preservation only 
to themselves ... the monument's action is not memory but fabulation' (168) they write, further explaining that 'creative fabulation has nothing to do with a memory ... or with a fantasy' (171).

Fabulation is thus conceived as a creative process through which the artist frees life by recurrent interventions, artistic practices that throw light on the virtual elements and possibilities that surround and condition what has been actualised, 'those visions fixed in time and space', or what Giacometti calls styles (Deleuze and Guattari 1994: 171). Virginia Woolf's literary modalities of expanding a moment into duration can easily be transferred from the plane of writing to the plane of painting, Deleuze and Guattari argue (172), through the channels of creative fabulation.

But here the question arises: how can the artist 'create the syntactical or plastic methods and materials necessary' for creative fabulation? (Deleuze and Guattari 1994: 173-4). If sensations, percepts and affects go beyond consciousness, feelings and memories, exceeding the actual, the lived, the narrated and the remembered, how can they be possibly expressed on the canvas without being dependent on a subject who feels and thinks, or rendered into referents of a symbolic object? How can a painter create a landscape that sees, or a portrait as a percept in the absence of woman? How could the mirror exist without the old woman it reflects? ${ }^{8}$ Deleuze notes that the opposition of the figure to the figurative is indeed a very subtle and precarious process. How can pure figures emerge in the canvas without having been contaminated by and restricted within the limitations and constraints of 'academic concerns' and figurative clichés, without having been facialised by despotic and passional regimes of signs?

This is indeed a difficult process, passing through a series of stages that Deleuze carefully delineates. The painter is first trying to clean her head and her canvas from figurative givens and clichés, what Deleuze calls the 'prepictorial figuration'; then she goes through 'the second figuration' when she tries to reconstitute the figure through the pictorial act (Deleuze 2003: 97). There is a thus a fort/da movement in painting: in her first encounter with the canvas, the painter has to step back, clean the canvas and her head, prepare her brain to become, according to Cézanne, 'a recording device, a receptacle of sensations' (in Doran 2001: 111); then she has to become attentive to her image, surrender herself to it, stop thinking and try to see, meditate. Only then will she become able to reconstitute a visual whole, 'a motif' for Cézanne or 'a diagram of forces' for Deleuze out of which a non-figurative figure might emerge. In Cézanne's thought, having a motif is indeed a crucial condition for art 
'to be realised' (in Doran 2001: 112). But what is a motif? The motif is a pictorial assemblage of sensations and becomings, the appearance in art of all the changes that continuously happen in the world and which we so often fail to notice. In Cézanne's poetics:

There must not be even one loose stitch, a gap where emotion, light and truth can escape. Try to understand, I guide my entire painting together all the time. I bring together all the scattered elements with the same energy and the same faith. Everything we see is fleeting, isn't it? Nature is always the same, but nothing about her that we see endures. Our art must convey a glimmer of her endurance with the elements, the appearance of all her changes. It must give us the sense of her eternity. (in Doran 2001: 110)

When Cézanne talks about Nature, he includes, of course, human nature, 'the nature which is out there ... and the nature which is in here' (in Doran 2001: 111). The motif is essential whether an artist paints a landscape or a portrait and in attaining her motif, the artist should strive to find harmony: 'we should find general harmony, like that expressed by colours' (in Doran 2001: 112). There is an exquisite moment in Cézanne's discourse on the idea of the motif-a sense of being bathed in colour while painting a portrait - that is reminiscent of John's monochromatic portraits of women:

Well, when I was painting Vieille au chapelet (Old Woman with a Rosary), I saw a tone of Flaubert, an atmosphere, something indefinable, a bluish and russet colour, which emanated, it seemed to me from Madam Bovary. In vain I tried reading Apuleius to chase away the obsession, which I feared would be too literary and would hurt my painting. Nothing worked. This great-bluishred aura descended over me and sang in my soul. I was completely bathed in it. (in Doran 2001: 112)

Maybe when John was painting her own Young Woman Holding a Rosary ${ }^{9}$ she might have felt being bathed in a blend of grey colours and tones that we can see in this painting as well as in the other three virtually identical paintings: The Pilgrim, ${ }^{10}$ Young Woman in a Grey Cloak ${ }^{11}$ and Woman with Cloak. ${ }^{12}$ Bathed in grey, like her portraits, John must have felt safely confirmed as an artist since, according to Cézanne, 'if a painter has never painted grey, he is not a painter' (in Doran 2001: 118). This feeling must have been reinforced by the enthusiastic letter of her Slade friend Michel Salaman who wrote to her in 1926 about the Pilgrim:

the you I hold tight to is the you of over twenty years ago and I suppose a different being to the one I am writing to; yet not entirely for I have your picture and there is so much of the Gwen I know in it that I love having it and want more. (cited in Langdale 1987: 165) 
Cézanne's fear for his painting 'not to be hurt', as expressed above, is also exemplary of the precariousness of moving beyond 'the figurative' that Deleuze's analysis has identified. How can the artist go through this narrow gorge, create conditions of possibility for pure 'figures' to emerge, and what would a move beyond 'the figurative' and the narrative entail? Lyotard (1971) addresses this question by delineating 'two ontologically distinct spaces: a textual space of recognisable coded entities and a figural space of metamorphosing unconscious forces' (cited in Bogue 2003: 115). The figural can thus have various manifestations, but Lyotard chooses Cézanne's paintings as an exemplar of the materialisation of the figural in painting. In doing so, he particularly points out how the Cézannean landscapes disrupt the homogeneity of space and raise an aesthetic awareness of the loss of visible unity. In this context Cézanne's landscapes become events for the manifestation of the figural.

Lyotard is further attentive to the form-figural relation: the figural traverses form without destroying it, but rather it opens form to its other (Gibson 1996: 62). Cézanne has lucidly grounded this rather abstract statement in reflecting on what the art of painting should grasp:

I mean that in this orange I am peeling, in an apple, a ball, a head, there is a culminating point, you see, and this point, in spite of terrible effects of light, shadow, colour sensations, is always the closest to our eye. The edges of objects fade towards another point on the horizon. ${ }^{13}$

The form of a subject or an object is therefore retained if it can be presented and seen in a single colour: 'in order to paint in the essence of the world, the vast world, one has to have the eyes of a painter who, in a single colour, sees the object, seizes it and relates it to other objects within [himself]' (Cézanne in Doran 2001: 121). Taking this proposition in John's paintings again, it is through the grey that the female figure emerges in The Pilgrim. The painting is not about a woman in grey: the grey constitutes the female figure; it becomes the woman that the painter or the viewer seizes and relates to other objects within herself. As Salaman aptly put it in his letter to John above: 'there is so much of the Gwen I know in it'.

Bogue has further noted that the textual/figural opposition should not be conflated with 'the traditional opposition between representational and nonrepresentational art' (Bogue 2003: 115). I would further add that establishing boundaries between the textual and the figural is in itself both problematic and impossible. One should rather try to discern volumes of the textual and the figural-perceived signs and 
pure sensation - in the work of art in general and in John's portraits in particular. As John was writing to Tyrwhitt, in August 1936, the object-or subject for that reason-in a painting is of no importance; a painter should only be concerned with what would work towards the harmony of the composition:

As to your drawing, I hope you will make a picture of it and as you were not satisfied with the fair figure put something else there, a pot of flowers for instance. Personally I thought the fair figure too important for a good composition and should have preferred a smaller object. ${ }^{14}$

John's epistolary advice to her friend on how to handle the problem of the 'fair figure' reminds us of Deleuze's take of the figural as a bloc of sensations, affects and the play of material forces, and therefore it is to the discussion of forces that the third analytical move of this paper will now turn.

\section{Forces, Rhythm and Form}

Gibson has suggested that the figural for Lyotard is an energetic space of forces and 'the liberation of forces is both an aesthetic and a political project' (Gibson 1996: 59). Lyotard, however, does not show how this liberation can be effectuated. Deleuze does this by drawing on Henri Maldiney's (1973) theory of rhythm and its relation to form. As Bogue notes, there is a distinction between perception and sensation in Maldiney's phenomenological theory of rhythm and form. ${ }^{15}$ As a rational organisation, perception comes after sensation, an extra-linguistic realm that humans share with animals and wherein unconscious and unreflective becomings occur. Sensation, Deleuze further notes 'is transmitted directly and avoids the detour and boredom of conveying a story' (Deleuze 2003: 36); it is already beyond narration. Movement is crucial in sensation, although in a spiral form of space/time interchanges. Thus the perceptual space of geography with its maps, systems of coordinates and fixed properties is contrasted to the sensory space of the landscape, 'a perspectival world enclosed by a horizon that constantly moves with us as we move' (117).

Art, therefore, for Maldiney renders visible the invisible realm of sensation and Deleuze takes up this thread when he argues that 'the task of painting is defined as the attempt to render visible forces that are not themselves visible' (Deleuze 2003: 56). Deleuze's argument is critically important in my analysis of John's figurative paintings and particularly her portraits and self-portraits: what I have found most 
intriguing in these paintings is the way they engulf the viewer in the sensory realm of forces that they have rendered visible. My interest has therefore moved towards exploring this plane of forces, unveiling more about their material and expressive roles, their form and their rhythm.

In following the above analytical interest in John's paintings, I have been drawn by Maldiney's suggestion that art 'is not a discourse [and thus] it is not made of signs but of forms' (Bogue 2003: 118). Just as signs for Deleuze (2001) are not restricted within the signifier-signified relation - they are not recognisable, but can only be sensed or felt - forms for Maldiney are not taken as 'static shapes or as sets of fixed relations; [they should rather be understood] dynamically as a process of spontaneous emergence and self-shaping' (Bogue 2003: 118). This is how form, as a process of 'autogenesis', is inextricably linked to rhythm, 'the unfolding pattern of the self-shaping activity' (Bogue 2003: 119).

Here again, Maldiney's conceptual couplet of form and rhythm as the style that the aesthetic concern should be about makes connection with the importance of rhythm in Deleuze's philosophy of difference and repetition. In the study of rhythm, according to Deleuze (2004), there is a distinction between static and dynamic repetition. Static or cadencerepetition should be perceived as 'an isochronic recurrence of identical elements' (Deleuze 2004: 23). Within dynamic or rhythm-repetition, however, 'tonic and intensive values act by creating inequalities or incommensurabilities between metrically equivalent periods of spaces' (23). Dynamic or rhythm-repetition in Deleuze is thus conceptually close to what is rhythm for Maldiney: 'this sense of form in formation, in perpetual transformation in the return of the same' (cited in Bogue 2003: 119).

The figural in John's paintings actually emerges as an effect of perpetual transformations of the figurative. Art historians and critics have particularly noted the repetition and recurrence of themes, gestures and postures in her paintings and particularly her portraits. ${ }^{16}$ These recurrences, however, are never mimetic repetitions. John's portraits create a musical rhythm of differences and repetitions that would fascinate her friends and fellow artists. As Salaman was writing to her after her only retrospective exhibition in 1926 at the Chenil Galleries in London:

It was indeed a chastening joy to stand there amongst those pale quiet songs of yours-like listening to the still music of the harpsichord-only there is nothing antique or archaistic about your work, they are so intensely modern in all but their peacefulness. (cited in Tickner 2004: 45) 
It is therefore to the unfolding of this rhythm in paintings that I will now turn: how does rhythm manifest itself in painting? Maldiney (1973) charts three planes in the unfolding of rhythm: 'a vertiginous disclosure of the chaotic world of sensation; a systolic condensation of element towards definite shapes; and a diastolic eruption of forces that dissolve those shapes' (cited in Bogue 2003: 119). We can have glimpses of these three movements in the manifestation of rhythm in artists' narratives, particularly when they talk about the unique experience of losing themselves in their canvas:

In order to paint a landscape correctly, first I have to discover the geographic strata. Imagine that the history of the world dates from the day when two atoms met, when two whirlwinds, two chemicals joined together. I can see rising these rainbows, these cosmic prisms, this dawn of ourselves above nothingness. I immerse myself in them when I read Lucretius. I breathe the virginity of the world in this fine rain. A sharp sense of nuances works on me. I feel myself coloured by all the nuances of infinity. At that moment, I am as one with my painting. We are an iridescent chaos. I come before my motif and I lose myself in it. I dream. I wander. Silently the sun penetrates my being, like a faraway friend. It warms my idleness, fertilizes it. We germinate. (Cézanne in Doran 2001: 114)

Cézanne's moment of being 'as one with my painting' becomes Maldiney's exemplar of the rising of the experience of sensation, the first movement in the manifestation of rhythm. John has left similar traces in her letters. As she was writing from Toulouse to her friend Tyrwhitt in the winter of 1903 :

I do wish you were here! You would like this place, it is very artistic - the country round is wonderful especially now - the trees are all colours. I paint my picture on the top of a hill- Toulouse lies below and all round me can see the country for many miles and in the far distance the Phryenees [Pyrenees]. I cannot tell you how wonderful it is when the sun goes down, the last two evenings have had a red sun-livid I think is the word, the scene is sublime then, it looks like Hell or Heaven. ${ }^{17}$

The 'iridescent chaos' for Cézanne, or the sublime scene of the sunset that 'looks like Hell or Heaven' for John create conditions of possibility for the work of art to emerge within the sensory plane; the process of systolic condensations as the second move in the manifestation of rhythm then follows. In the Cézannean world of artistic creation again:

The next day, a beautiful morning, slowly geographical foundations appear, the layers, the major planes form themselves on my canvas. Mentally I compose the rosy skeleton. I can see the outcropping of stones under the 
water, the sky weighs on me. Everything falls into place. A pale palpitation envelops the linear elements. The red earths rise from an abyss. I begin to separate myself from the landscape, to see it. (Cézanne in Doran 2001: 114)

In John's notebooks, there is a poetic entry on 30 August 1922, marking this moment of systolic condensations when the artist detaches herself from the chaotic wholeness of the sublime and focuses on specific shapes and forms, repossesses things that she thought she had known, tries to see them again, rediscovers their forms:

$1^{\text {st }}$ thought.

Turn gently toward your work.

Instead of this sudden discouragement and sadness take up in your mind a leaf, a flower, a simple little form and find its form, take it into your possessions as it were.

$2^{\text {nd }}$. Every day you may add to your possessions - every flower and leaf and other things may be taken possession of as it were. You have seen nearly everything vaguely. ${ }^{18}$

By asking her imaginative interlocutor to 'take a simple little form and find its form', John seems to adopt Maldiney's distinction between form as a static shape and form in formation, or rather perpetual transformation as discussed above. We tend to consider forms as static shapes, only because 'we have seen everything vaguely', according to John above. It is the artist's work to repossess things, try to look at them more closely, so that she can create forms of the invisible sensory realms, the virtual worlds that surround us. But in doing so, the artist has already entered the third plane of diastolic eruptions, she has unleashed the forces of the figural that Lyotard's analysis has pointed to, although not sufficiently analysed. This is the moment for Cézanne when painting starts, colours take over and forms and shapes dissolve once again:

With the first sketch, I detach myself from these geological lines. Geometry measures the earth. A feeling of tenderness comes over me. Some roots of this emotion raise the sap, the colours! An airborne, colourful logic quickly replaces the sombre stubborn geography. Everything becomes organised: trees, fields, houses. I see. By patches: the geographical strata, the preparatory work, the world of drawing all cave in, collapse as in a catastrophe. A cataclysm has carried it away, regenerated it. A new era is born. The true one! The one in which nothing escapes me, where everything is dense and fluid at the same time, natural. All that remains is colour, and in colour, brightness, clarity, the being who imagines them, this ascent from the earth 
towards the sun, this exhalation from the depths towards love ... Everything drops. Everything falls into the horizon. From my brain onto my canvas, from my canvas towards the earth. (Cézanne in Doran 2001: 114-15)

On the diastolic plane then, it is colour that matters, unleashing sensory forces but keeping them together in the experience of the aesthetic. John's artistic strength was indeed in the realm of colours; her 'fine sense of tone' was duly noted by her teacher Whistler, as recorded in herbrother's autobiography:

Mr Whistler with great politeness asked me to make Gwen his compliments. I ventured to inquire if he thought well of her progress, adding that I thought her drawings showed a feeling for character. 'Character?' replied Whistler. 'Character? What's that? It's tone that matters. Your sister has a fine sense of tone.' (John 1954: 45; original emphasis)

John's attention to colours has further been noted by her biographer: 'she revealed that she had begun to work with a colour wheel [which] consisted of several layers of revolving discs of colour charts so that it was possible by turning the different layers, to arrive at compatible tones' (Roe 2002: 255). Her biographer draws here on John's notebooks, which carry traces of how preoccupied she was with thinking around forms, colours and tones. Indeed, John's notebook entries inscribed the phases of prepictorial figuration and second figuration as discussed by Deleuze above:

11 March $1920^{19}$

Method of application

1. On seeing the subject note the form, the colour, the tones.

2. Meditation, Decision on the form, the colour, etc

3. The painting. (To save time mix the colours beforehand)

April $1921^{20}$

Method of observation

1. the strangeness

2. colour

3. tones

4. personal form

Having gone through the phases of application and observation when the painter has to clean her head and her canvas from pre-given figurations and clichés, she then moves to the phase of second figuration or 'the method of execution' in her own terms: 
Method of execution ${ }^{21}$

1. observation of the 4 points

2. mixing of colours

3. lines in pencil for eye training

4. painting of personal forms out of 9 f background

As Maldiney (1973) reminds us again, having considered the interchange of systolic condensations and diastolic eruptions emerging from the sensory chaos in the process of creativity, we can now see more clearly how rhythm arises as the time of 'form in formation' as discussed above. Clearly this rhythm cannot be externally regulated, but rather creates 'its own temporal framework, and when we experience the artwork we also enter into the implicated time of its form, a perpetual Now outside commonsense coordinate' (Bogue 2003: 121).

So far in this section, I have looked into the unfolding of the form-rhythm relation within Maldiney's three phases of sense experience, whereby form and matter are inextricably linked. But the matter of form in painting is the canvas and the colours. In the next section I want to focus on the play of colours in the realm of sensation. This will be the fourth move in the rhythm of my analysis of John's later paintings.

\section{On Colours}

'The colour system itself is a system of direct action on the nervous system' argues Deleuze (2003: 52). But how do colours intervene in rendering visible forces that are themselves invisible, how do they play around visible bodies and objects in the process of artistic creation and reception? Deleuze is very careful in distancing Cézanne's idea of the role of colours from that of the Impressionists:

sensation is not in the 'free' or disembodied play of light and colour (impressions); on the contrary it is in the body ... Colour is in the body, sensation is in the body and not in the air. Sensation is what is painted. What is painted on the canvas is the body, not insofar as it is represented as an object, but insofar as it is experienced as sustaining this sensation. (Deleuze 2003: 35)

Charting a diagram of forces is Deleuze's suggestion for coming to terms with sensation in painting, and his concept of the diagram runs in parallel with the Cézannean 'motif' as explicated above. 'Painting elevates colours and lines to the state of language' Deleuze notes 
(Deleuze 2003: 113), his argument resonating again with Cézanne's idea that 'words and colours have meaning' (cited in Lloyd-Morgan 2004: 127). But the language Deleuze refers to is an 'analogical' language, which is opposed to the 'digital' language of overcoded discursive utterances and 'consists of expressive movements, paralinguistic signs, breaths and screams and so on' (Deleuze 2003: 113). The analogical language can be sensed and felt, but never recognised or learned.

So how does painting work as an analogical language? According to Deleuze, it has three dimensions: planes, colours and bodies (Deleuze 2003: 118). Colour seems to be the most important of the three, since 'analogy finds its highest law in the treatment of colours' (120). Deleuze further discusses the process of modulation, drawing on Gilbert Simondon's (1964) critique of the matter/form opposition and his argument that 'forms are determined through the establishment of a particular regulation of energy' (Bogue 2003: 134). Modulation and mould are inextricably linked in Simondon's analysis: 'to mould is to modulate in a definitive manner, to modulate is to mould in a continuous and variable manner' (cited in Deleuze 2003: 192), and therefore colourism is a process of modulation and moulding.

How then does the modulation of colour participate in the formrhythm relation that keeps together the three moments of the experience of sensation? Colourism discloses the sensory world of the landscape and intervenes in the systolic moments wherein the forms of subjects and objects are in the process of becoming: colours do not fill in pre-existing forms, but rather liberate lines, figures and objects, unleash forces of continuous transformation of the form and thus create conditions of possibility for the diastolic moment of mingling again subjects and objects with their surrounding world. As has been reported by Joaquim Gasquet, Cézanne thought that 'there is only one route for rendering everything, for translating everything: colour. Colour is biological ... Colour is living, all alone it breathes life into things' (in Doran 2001: 120).

Deleuze enumerates the 'practical rules of colourism', particularly stressing the 'broken tones' in Bacon's work. Broken tones emerge when primary and complementary colours are mixed in unequal proportions, "the addition of a bit of orange to blue [yields] a "broken" muddy blue' (Bogue 2003: 151). 'Colourism' then, Deleuze argues, 'consists of relations of warm and cool, of expansion and contraction' but also of 'regimes of colour, the relations between these regimes and the harmonies between pure tones and broken tones' (Deleuze 2003: 152). Having discussed the importance of colour in Deleuze's analytics, 
I will now consider John's particular practices of colour modulation, which create conditions of possibility for forces to be released from her paintings and for her figures to enter the process of becoming imperceptible.

\section{Colourism, Forces and Figures in John's Portraits}

As already discussed, the problem of painting for Deleuze is not to reproduce or even invent forms, but to capture forces. But what does this mean? Force in Deleuze's approach is closely related to sensation. While, however, the play of forces creates conditions of possibility for sensation to be felt, and painting renders the artist's sensations visible through colour, force itself cannot be sensed, felt or experienced, since the sensation 'gives something completely different from the forces that condition it' (Deleuze 2003: 56). Thus the attempt to capture the ever dissolving and disappearing forces, charting, as it were, the conditions of sensation becomes the problem of painting.

Since what can be sensed is the effects of forces, the problem of capturing forces in the history of painting was conflated with the problem of decomposing and recomposing effects, Deleuze notes (2003: 57-8). However, the problem of how invisible forces can be made visible remained largely unaddressed, till it became central in Bacon's work. I want to consider this problem in John's portraits, revisiting the connections between Bacon and Cézanne - as discussed by Deleuze - and Cézanne's notion of sensation.

Cézanne's influence on John has been noted by her biographers and art critics $^{22}$ and has been inscribed in her letters. As she was writing to Tyrwhitt on 30 August 1936: 'Oh a sudden thought! Perhaps you would like to read a little book I have about Cézanne. I'll put it in with the others. It is very precious to me so please send it back or bring it in October. ${ }^{23}$ Cézanne's notion of sensation would be the epigraph John chose for the only solo exhibition that she had in 1926 at the Chenil Galleries in Chelsea. John had further used Cézanne's notion of realisation of a work of art to talk about the need to 'realise' her little paintings. As she was writing to Tyrwhitt in the same letter above: 'I am tired of not knowing how to realise my little paintings (realise is Cézanne). I think finish would be a better word in my case. ${ }^{24}$ But how has such 'realisation' actually occurred?

It has to be noted here that John's art went through a radical transformation after her move to Paris in 1904; by the late 1910s she had abandoned the academic layered technique and had been intensely 
working with colour, which she applied directly on the canvas without preparatory drawings, 'in short dabs and flicks from a well-loaded brush [appearing] to skip across the tops of the canvas weave' (Bustin 2004: 196, 198). John's technique of '[dabbing] colour on in a lively mosaic of short strokes' (Tickner 2004: 38) blurred the boundaries between figure and ground. Moreover the interplay of colours and subtle lines was creating a musical effect: 'The subtly irregular contours, ashy colours and minor variations of tone vibrate in the eye, producing something like a visual equivalent to musical resonance' (Tickner 2004: 38).

John's figures therefore emerge through the rhythm of the systolic and diastolic movements of sensation - her colours engender 'rhythmic characters' (Deleuze 2003: 72). Rhythm in her paintings, however, is not attached to her figures. As in Bacon's paintings, in John's later portraits 'it is rhythm itself that would become the Figure, that would constitute the Figure' (Deleuze 2003: 71). The rhythm/figures of John's later paintings are usually two-third or three-quarter length with pyramidal bodies and small heads, often out of proportion, their background is plain, both chromatically and structurally, while the distinction between figure and ground is always blurring. The body posture is equally simple and immobile: arms held close to the body, hands folded or holding a book, a letter, a piece of fabric or a black cat. There are slight changes in the appearance of the figure: their hair can be loose or plaited and they are usually enfolded in dresses or cloaks of broken tones that sometimes give the title of the composition: Girl in a Blue Dress, ${ }^{25}$ Girl in a Green Dress, ${ }^{26}$ Girl in a Mulberry Dress, ${ }^{27}$ Young Woman in a Grey Cloak. ${ }^{28}$ Sometimes the figures wear hats or very minimal jewellery or other accessories that are again inscribed in the title of the painting: Young Woman Wearing a Large Hat, ${ }^{29}$ Woman with a Coral Necklace, ${ }^{30}$ Portrait of a Young Woman Wearing a Locket, ${ }^{31}$ Seating Woman Wearing a Blue Bow, ${ }^{32}$ Young Woman in a Red Shawl, ${ }^{33}$ Girl with a Blue Scarf. ${ }^{34}$

It almost seems that the hats, bows, shawls, scarves, necklaces and the colours of the dresses matter much more than the actual figures. If the work of art is a bloc of sensations, 'sensation refers only to its material: it is the percept or affect of the material itself, the smile of oil' (Deleuze and Guattari 1994: 166). Emerging from an assemblage of sensations, percepts and affect, John's female figures sustain the chromatic composition of the picture and animate the play of colours and tones that seem to be the main preoccupation of the artist. After all, the sitter can be no more than 'an affair of volumes' in John's letter that has initiated this paper. Moreover, in many of John's later portraits there 
are some deliberately unfinished areas of canvas as in La Petite Modèle. ${ }^{35}$ Cézanne's influence is striking here: 'colour sensations, which make light in my paintings, create abstractions that keep me from covering my canvas or defining the edges of objects where they delicately touch other objects, with the result that my image or picture is incomplete', Cézanne was writing to Emile Bernard on 23 October 1905 (in Doran 2001: 48). As John's notebooks show, unfinished, elusive and seemingly without details as they are presented, her portraits have nevertheless been carefully thought of, in many more details than we are allowed to perceive:

\section{March $1932^{36}$}

The making of the portrait:

The strange form.

The pose and proportions.

The atmosphere and notes, the tones.

The finding of the forms (the sphere-the hair, the forehead, the cheek, the eye, the nose, the mouth, the neck, the chin, the torse).

Blobbing

the sculpting with the heads.

John's methodical approach to the realisation of a portrait seems to follow Cézanne's suggestion: 'You have to have a method ... People have to play games. That's what I search for in painting. I don't have a doctrine like Bertrand, but you have to have theories, sensations and theories' (in Doran 2001: 94). Art historians and critics have thus characterised John's pictures as a debt to Cézanne. 'The two artists share a detached approach to the figure and both arrange their models in severe, simple poses' (Jenkins and Stephens 2004: 148). In this light, details were not important and when they appeared, they would only function as compositional elements, colour events, as I will further suggest.

Like Cézanne then, John's attention was directed to the depth of her portraits not the surface: 'one can alter, decorate, caress the surface, but one can't touch depth without touching truth ... I would rather smash my canvas than invent or imagine a detail', Cézanne had written (in Doran 2001: 117). Although indifferent to mundane details, John was, however, very much interested in painting extraordinary details, blots of paint that would irrupt in her canvas to compose the harmony of colours she was attaining to reach. In this light, she would use colour to chart diagrams of what Deleuze has called 'asignifying traits', 'involuntary free marks lining the canvas' (Deleuze 2003: 5); these traits do not carry any 
symbolism, they are not metaphors, 'they are devoid of any illustrative or narrative function' (5) and 'mark the emergence of another world' (100). In this light, the tiny bunch of flowers on Mère Poussepins' table ${ }^{37}$ or the red and blue feathers in The Japanese Doll ${ }^{38}$ create a fine balance between 'descriptive sign' and 'coloured matter' (Tickner 2004: 29); they become, I suggest, colour events that spring from the canvas blurring the boundaries between the figural and the figurative as in Deleuze's analysis above. Colourism lies indeed at the heart of what truth in portraiture should revolve around.

Thus, the painting of a portrait for John-carefully mediated as it was-becomes a Deleuzian diagram or a Cézannean motif, 'something that combines sensation and the solidity of a framework' (Bogue 2003:

132). Cézanne's motif was of course a view of the Mont Saint-Victoire, a great pointed mountain in the area of Aix-en-Provence. ${ }^{39}$ As Tickner has pithily commented, the figure of The Convalescent ${ }^{40}$ painted more than fifty times was John's Mont Saint-Victoire, her motif(Tickner 2004: 39).

I have already discussed above John's preoccupation with forms, tones and colours and the way she kept experimenting with her paintings, moving away from the academic conventions of her art education. Her notebooks and contemporary close examination of her paintings have shown that experimentation did not mean contingency and accidental use of colour. In Cézanne's thought, 'the artist can never be too conscientious, or too sincere, or too submissive to nature, but [he] must be more or less master of [his] subject and above all his means of expression [adapting] them to his motif' (in Doran 2001: 121). John's notebooks show indeed that she was adopting an analytical approach that she kept revisiting and reviewing. She was in a way very attentive to the charting of her diagram, following perhaps, as Bustin has commented, Whistler's exhortation to 'distrust everything you have done without understanding it ... You must know how you did it, that the next time you can do it again' (Bustin 2004: 196). John's analytical approach is reflected in her work and has been textualised in her letters since the very early stages of her career.

What I therefore suggest is that there is an interplay of volumes of the textual and the figural-perceived signs and pure sensation-in John's portraits, effectuated through her distinct pictorial acts, her own colourism. But how can we discern the play of forces in these portraits? Drawing on the three fundamental elements that Deleuze identifies in Bacon's paintings, namely Structure, Figure and Contour (Deleuze 2003: 144), I will consider the first two in John's portraits: her structuring monochromatic fields and the sitting female figures. 
Indeed, the monochromatic fields of the later portraits are fundamental elements of John's compositions. Static and motionless as these female figures seem to be, they are mapped in a field of invisible forces moving in different directions and with different intensities. Following Deleuze's discussion of Bacon's paintings, I will thus make a diagram of the forces that John's portraits render visible.

\section{Charting Forces in John's Portraits}

As already discussed, John's portraits follow the rhythm of systolic and diastolic movements in Deleuze's analysis: the systole delineates the figure and goes from the structure - the monochromatic field - to the figure, while the diastole sends out forces that extend the body to the structure of the painting and beyond it to the realm of sensation shared by the viewer. I have already discussed the unfolding of the rhythm of the systolic and diastolic movements in the art of painting. Here, I want to focus on the diastolic phase and particularly the forces unleashed by the work of art and shared by the viewers. What I suggest is that in John's later portraits, the monochromatic fields enveloping the female figures create the stage for forces of solitude to leap out from the canvas and make connections with forces of the Woman-becoming imperceptible. ${ }^{41}$

As most art critics have noted about John's portraits, her sitters appear motionless and impassive; they seem to do nothing more than just looking, maybe reading a book or a letter, holding a rose, a piece of fabric, a rosary or a cat in their lap. ${ }^{42}$ Frozen in time and lost in space, the figural image is nevertheless 'the focus of intense concentration [and through] the fine discriminations of tone, the desaturated colour harmonies, [it] requires us to peer fixedly, . . . to respond to her attentiveness with our own' (Tickner 2004: 40).

Bathed in the colours of the monochromatic field, John's figure gradually dissolves in the bare background and the Woman, who loves and cares and offers her self as a spectacle to the gaze of the other, enters the cycle of becoming imperceptible. Driven by the force of the colours, the face breaks the despotic white wall without disappearing in the passional black hole, following lines of flight from striated regimes of signs. As Tickner has eloquently put it: 'Gwen's broken application and feathered contours dissolve the figure into its surroundings, giving the impression of a slight vibration as though the air was fizzing with dust-motes' (Tickner 2004: 45). Thus the monochromatic fields absorb the figure, making visible the forces of her becoming imperceptible. 
Indeed, the female figures of John's portraits, I argue, emerge as events, idealised representations of femininity deterritorialised from domesticity and being connected to the world of absent-mindness; this was the sphere of creativity and pure thinking that John and her friends had experienced during their years at the Slade but had lost after their marriage. Edna Clarke Hall (née Waugh), who had studied at the Slade with John, would mostly fervently express her will for privacy and solitude and the need to be 'absent-minded' in a letter to Ida Nettleship ${ }^{43}$ written in the autumn of 1906 :

It is a tremendous tax to have children always at hand for whom one is responsible without feeling an intimate love in their personalities ... I never paint now partly because I have very little time and chiefly because I can never allow myself to be absent-minded. (cited in Thomas 2007: 97-8)

It is this existential need for being absent-minded that John's portraits capture, visually expressing a notable phrase from her notebooks entered on 11 July 1922: 'I don't live when I spend time without thought' (cited in Tickner 2004: 41). John's repetitive portraits of absent-minded women should not therefore be seen as a series of attempts to capture the essence of her sitter but as pictorial acts creating a rhythm of difference and repetition, engaging with the logic of sensation in painting. As Tickner has noted, 'repetition in [John's] work is better understood as a typically modernist engagement with the process of picture-making as the work is tested through repeated confrontations with an identical motif' (Tickner 2004: 39).

But there are more things happening in John's portraits as the forces of solitude and imperceptibility that leap out from the canvas dismantle and reconfigure boundaries not only between the painter and the sitter, but also between the viewer, the sitter and the painter, the self and other. John was indeed a noticeable presence as a painter sending out strong emotions and affects to her sitters. She was definitely following Cézanne's advice that 'one must look at the model and feel very exactly ... express oneself distinctly and with force' ${ }^{44}$ Jeanne Robert Foster, her American patron's partner, had definitely felt this force and did write about the unique experience of sitting for John in a letter to John Quinn on 16 September 1921:

She cannot endure having the pose changed by a hairs breadth after she has arranged it. She takes down my hair and does it like her own. She wants to draw the shape of my head. She has made me sit as she does and I feel the absorption of her personality as I sit. She is very much annoyed with necklaces 
and bracelets ... She is more myself than I am when I am with her. (Foster cited in Langdale 1987: 89)

There is an intense play of forces between the painter and the sitter making connections between the self and other. Gasquet has reported this unique and intensive relationship between the painter and the sitter in observing Cézanne painting the portrait of his father:

Most of the time, even though he had his brushes and his palette in his hand, Cézanne looked at my father's face, examined it. He didn't paint. From time to time, with a trembling stroke of the brush, he laid on a thin touch, a bright stroke of blue, which defined an expression or brought out and highlighted a fleeting aspect of his character. (Gasquet in Doran 2001: 147)

The force of this unique I-you relationship that Gasquet recounts above and Foster expresses in her letter to Quinn-I exist through you and you become me when you paint me - radically opens up the self to the other and sets up a narratable scene into which the viewer him- or herself is irresistibly drawn. ${ }^{45}$ The imperceptible female figures of John's portraits force the viewers to raise existential questions about themselves and the world, they interrogate the ethics and aesthetics of what human communication entails and they leave signs of an experience of time as duration (Bergson 2002), the impossibility and greatness of grasping a moment in time, momentarily living in the present. Sensory experiences of seizing the moment are invoked by the fine interplay between the ordinary and the extraordinary in many of John's paintings wherein 'unremarkable objects and ordinary people are imbued with radiance and rendered beautiful' (Tickner 2004: 45). But as Tickner further notes, beauty is very differently grasped in John's paintings:

It is not a question of beauty ... through an idealisation of the intrinsic qualities of a particular woman ... It is rather to do with the way in which a certain kind of ordinariness, subjected to an intense beam of attention but depicted with a kind of calculated austerity ... can evoke this feeling of delight, desire, pleasure and resignation ... Something ordinary, something slipped beneath the horizon of our attention like a breath or a heartbeat, is recovered, transfigured and made luminous. (Tickner 2004: 45)

This beauty springing from the ordinary rendered extraordinary through the art of colour forces John's viewers to wonder: why haven't I noticed this little bunch of flowers or that red feather before, what is this world around me, what is this present that I find myself in and what am I doing here? These are existential questions that arise from John's own colourism, her 'oyster-whites, blue greys and duns, the closely 
graded tones and occasional accents of colour' (Tickner 2004: 45). Thus, following Cézanne's wish 'to paint space and time and make them forms of the sensibility of colours' (in Doran 2001: 124), John has painted images that have inspired her viewers to reimagine women and women's times to come.

\section{Notes}

1. Gwen John (1876-1939) was born in Wales, studied at the Slade and moved to Paris in 1904 where she lived and worked till the end of her life. Her long affair with Auguste Rodin has been discussed at length in her two biographies (Chitty 1987; Roe 2002) and a series of art history monographs (Langdale 1987; Taubman 1985; Foster 1999). See Tamboukou 2010 for an extended discussion of her letters.

2. For a critical appreciation of John's work see Langdale 1987; Foster 1999; Taubman 1985; Jenkins and Stephens 2004.

3. See Deleuze and Guattari 1988, particularly chapter 5: 'On Several Regimes of Signs'.

4. As the subject of this essay is a woman, the painter is treated as feminine throughout.

5. Cézanne's letter to Emile Bernard, 15/04/1904 (in Doran 2001: 29).

6. In its Deleuzian configuration within a long philosophical tradition that goes back to the Stoics, 'the event is not what occurs (an accident), it is rather inside what occurs, the purely expressed. It signals and awaits us ... it is what must be understood, willed and represented in that which occurs' (Deleuze 2001: 170).

7. See Deleuze 2003, particularly the chapter 'Every Painter Recapitulates the History of Painting', pp. 122-43. It also has to be noted here that Deleuze sees painting as 'an analogical language' (Deleuze 2003: 113), a concept that I will discuss in the fourth section of the paper.

8. Here I paraphrase and play with Deleuze and Guattari's questions in chapter 7 of What Is Philosophy? (Deleuze and Guattari 1994: 169).

9. Langdale 1987: 165 , pl. 231 , cat. no: 108.

10. Langdale 1987: 87, pl. 127, cat. no: 107. See < http://www.wikigallery.org/ wiki/painting_198025/Gwen-John/The-Pilgrim > (accessed 24 January 2014).

11. Langdale 1987: 166, pl. 232, cat. no: 109. National Gallery of Canada, Ottawa. See <http://cybermuse.gallery.ca/cybermuse/search/artwork_e.jsp?mkey=2392 > (accessed 24 January 2014).

12. Langdale (1987: 167), pl. 233, cat. no: 166. See < http://www.davidrumsey. com/amica/amico545515-6900.html > (accessed 24 January 2014).

13. Letter to Bernard, 25/7/1904 (in Doran 2001: 46).

14. NLW MS 21468D, f. 180.

15. Maldiney has drawn on Straus and Merleau-Ponty in his understanding of sensation as a kind of autopoesis. See Grosz 2008: 83.

16. See Langdale 1987, particularly chapter 4; Foster 1999, particularly chapter 6; Tickner 2004: 39; Jenkins and Stephens (2004: 148).

17. NLW MS 21468D, ff. 7a-7b.

18. Notebook entries (in Lloyd-Morgan 2004: 128).

19. Notebook entry (in Lloyd-Morgan 2004: 112).

20. Notebook entry (in Lloyd-Morgan 2004: 117).

21. Notebook entry (in Lloyd-Morgan 2004: 118). 
22. See Roe 2002; Langdale (1987: 97); Tickner (2004: 39).

23. NLW MS 21468D, ff. 182v; original emphasis.

24. NLW MS 21468D, ff. $182 \mathrm{v}$.

25. Langdale 1987: 144, pl. 190, cat. no: 32. National Museum of Wales. See $<$ http://www.museumwales.ac.uk/en/art/online/?action=show_item\&item= $1018>$ (accessed 24 January 2014).

26. Langdale (1987: 96), pl. 148, cat. no: 99. National Museum of Wales. See < http://www.museumwales.ac.uk/en/art/online/?action=show_item\&item= $1019>$ (accessed 24 January 2014).

27. Langdale 1987: 147, pl. 247, cat. no: 136. Southampton Art Gallery. See < http://www.wikigallery.org/wiki/painting_198138/Gwen-John/Girl-in-aMulberry-Dress $>$ (accessed 24 January 2014).

28. Langdale 1987: 166, pl. 232, cat. no: 109. See < http://cybermuse.gallery. $\mathrm{ca} /$ cybermuse/search/artwork_e.jsp?mkey=2392 $>$ (accessed 24 January 2014).

29. Langdale 1987: 98, pl. 150, cat. no: 101. See < http://www.wikigallery.org/wiki/ painting_198125/Gwen-John/Young-Woman-Wearing-a-Large-Hat > (accessed 24 January 2014).

30. Langdale 1987: 162, pl. 224, cat. no: 96. See < http://www.wikigallery.org/ wiki/painting_198132/Gwen-John/Woman-in-a-Coral-Necklace > (accessed 24 January 2014).

31. Langdale 1987: 160, pl. 144, cat. no: 88 . See < http://davisandlangdale. homestead.com/Pages/GJohnS09.html > (accessed 24 January 2014).

32. Langdale 1987: 96 , pl. 147, cat. no: 95.

33. Langdale 1987: 164, pl. 227, cat. no: 102. York Art Gallery. See $<$ http://www.wikigallery.org/wiki/painting_198040/Gwen-John/Young-Womanin-a-Red-Shawl $>$ (accessed 24 January 2014).

34. Langdale 1987: 89, pl. 131, cat. no: 133.

35. Langdale 1987: 79, pl. 117 , cat. no: 62 .

36. Notebook entries (in Lloyd-Morgan 2004: 177-8).

37. Langdale 1987: 147, pl. 196, cat. no: 39. See < http://www.wikigallery.org/ wiki/painting_198136/Gwen-John/Mere-Poussepin-Seated-at-aTable $>$ (accessed 24 January 2014).

38. Langdale 1987: 82, pl. 119, cat. no: 126. National Museum and Galleries of Wales. See < http://www.wikigallery.org/wiki/painting_198023/Gwen-John/ The-Japanese-Doll $>$ (accessed 24 January 2014).

39. See Doran 2001: 94.

40. Langdale 1987: 95, pl. 146, cat. no: 92. Fitzwilliam Museum, Cambridge. See < http://www.wikigallery.org/wiki/painting_198129/Gwen-John/TheConvalescent $>$ (accessed 24 January 2014).

41. 'Woman' in upper case denotes here the figure of the woman within the striated spaces and discourses of a patriarchal regime of signs.

42. See for example Girl with a Cat on her Lap (< http://www.wikigallery. org/wiki/painting_198133/Gwen-John/Girl-with-a-Cat-on-her-Lap >); Girl in Profile (< http://www.wikigallery.org/wiki/painting_198134/Gwen-John/Girlin-Profile >); Girl in Rose (< http://www.wikigallery.org/wiki/painting_198029/ Gwen-John/Girl-in-Rose >); Girl Holding a Rose ( $<$ http://www.wikigallery. org/wiki/painting_198124/Gwen-John/Girl-Holding-a-Rose >) (all accessed 24 January 2014).

43. Nettleship was also John's fellow student at the Slade and later became Augustus John's first wife.

44. Letter to Bernard, 12 May 1904 (in Doran 2001: 30).

45. Narratability here is taken from Cavarero's (2000) philosophy that I have discussed elsewhere at length (see Tamboukou 2010). 


\section{References}

Bergson, Henri [1893] (2002) Matter and Memory, trans. Nancy M. Paul and W. Scott Palmer, New York: Zone Books.

Bogue, Ronald (2003) Deleuze on Music, Painting and the Arts, London: Routledge. Bustin, Mary (2004) 'The Rules or Problems of Painting: Gwen John's Later Painting Techniques', in D. F. Jenkins and C. Stephens (eds), Gwen John and Augustus John, London: Tate Publishing, pp. 196-202.

Cavarero, Adriana [1997] (2000) Relating Narratives: Storytelling and Selfhood, trans. Paul A. Kottman, London: Routledge.

Chitty, Susan (1987) Gwen John, New York: Franklin Watts.

Deleuze, Gilles [1969] (2001) The Logic of Sense, trans. M. Lester, London: Continuum.

Deleuze, Gilles [1981] (2003) Francis Bacon: The Logic of Sensation, trans. D. W. Smith, London: Continuum.

Deleuze, Gilles [1968] (2004) Difference and Repetition, trans. Paul Patton, London: Continuum.

Deleuze, Gilles and Félix Guattari [1980] (1988) A Thousand Plateaus: Capitalism and Schizophrenia, trans. Brian Massumi, London: Athlone Press.

Deleuze, Gilles and Félix Guattari (1994) What Is Philosophy?, trans. Hugh Tomlinson and Graham Burchill, London: Verso.

Doran, Michael (ed.) (2001) Conversations with Cézanne, trans. Julie Lawrence Cochran, Berkeley: University of California Press.

Foster, Alicia (1999) Gwen John, London: Tate Gallery Publishing.

Gibson, Andrew (1996) Towards a Postmodern Theory of Narrative, Edinburgh: Edinburgh University Press.

Grosz, Elizabeth (2008) Chaos, Territory, Art: Deleuze and the Framing of the Earth, New York: Columbia University Press.

Jenkins, David Fraser and Chris Stephens (eds) (2004) Gwen John and Augustus John, London: Tate Publishing.

John, Augustus (1954) Chiaroscuro, London: Jonathan Cape.

Langdale, Cecily (1987) Gwen John, With a Catalogue Raisonne of the Paintings and a Selection of the Drawings, New Haven, CT: Yale University Press.

Lloyd-Morgan, Ceridwen (2004) Gwen John: Letters and Notebooks, London: Tate Publishing in association with the National Library of Wales.

Lyotard, Jean-François (1971) Discours, Figure, Paris: Klincksieck.

Maldiney, Henri (1973) Regard Parole Espace, Lausanne: Editions l'Age d'Homme.

National Library of Wales, Archives, Gwen John's papers (NLW MS).

Roe, Sue (2002) Gwen John, A Life, London: Vintage.

Simondon, Gilbert (1964) L'Individu et sa genèse physico-biologique, Paris: Press Universitaires de France.

Tamboukou, Maria (2010) Nomadic Narratives, Visual Forces: Gwen John's Letters and Paintings, New York: Peter Lang.

Taubman, Mary (1985) Gwen John: The Artist and her Work, Ithaca, NY: Cornell University Press.

Thomas, Alison (2007) Portraits of Women: Gwen John and her Forgotten Contemporaries, Cambridge: Polity Press. 